\title{
INTEGRATED EFFECT OF METEOROLOGY, AIR POLLUTION AND SURFACE OZONE ON CROWN CONDITION AND STEM INCREMENT OF SCOTS PINE TREES UNDER DIFFERENT SITE CONDITIONS
}

\author{
Giedrius ŠIDLAUSKAS, Institute of Forest Management and Wood Science, Faculty of Forestry and Ecology, Alekandras Stulginskis \\ University, Studentų st. 11 LT-53361, Akademy, Kaunas distr., Lithuania, giedrius.asu@ gmail.com (corresponding author) \\ Marius MIKALAJŪNAS, Institute of Forest Management and Wood Science, Faculty of Forestry and Ecology, Alekandras Stulginskis \\ University, Studentų st. 11 LT-53361, Akademy, Kaunas distr., Lithuania, marius.mikalajunas1990@ gmail.com \\ Ainis PIVORAS, Institute of Forest Management and Wood Science, Faculty of Forestry and Ecology, Alekandras Stulginskis University, \\ Studentų st. 11 LT-53361, Akademy, Kaunas distr., Lithuania, apivoras@ gmail.com \\ Inga JUONYTE், Faculty of Forestry and Ecology, Alekandras Stulginskis UniversityStudentu st. 11, LT-53361 Academy, Kaunas distr. \\ Lithuania, ingajuonyte1995@gmail.com \\ Gintaras PIVORAS, Faculty of Forestry and Ecology, Alekandras Stulginskis University, Studentų st. 11 LT-53361, Akademy, Kaunas \\ distr., Lithuania, gpivoras@gmail.com
}

\begin{abstract}
Adaptation of the local tree species to recent environmental conditions rather often is found to be very low even when it affects tree health integrally with air pollutants, and surface ozone. The aim of the study was to quantify the relationships between environmental factors, annual stem basal area increment and crown defoliation of Scots pine trees located in the north-eastern part of Lithuania. The obtained data revealed that Scots pine is the most sensitive species to environmental changes. Its reaction to both negative and favorable environmental factors was best expressed, what indicated its highest level of resilience and adaptive capacity to recent global changes. Air concentrations of sulphur species and ammonium as well as their deposition were the main drivers resulting in changes in mean defoliation of Scots pine trees in Lithuania. The data on stem basal area increment collected on two different forest sites (FS): mineral olygotrophic and organic mesoeutrophic soils confirmed that since the 1980 growing season the annual increment of the pine trees has increased. The causes of this rapid growth were as follows: higher air temperatures during the dormant period and, to a lower extent, the higher temperatures from May through August. The effect of precipitation was negligible. During vegetation nitrate deposition as fertilizing compound stimulated the pine tree stem BAI formation especially on mineral soil FS. Negative ozone effect on pine growth intensity was significant for pine trees on mineral soil FS. Higher moisture regime significantly increased the tolerance of pine trees to the negative effect of air concentration of acidifying compounds, their wet deposition and surface ozone. The study is based on the results obtained conducting national project supported by Lithuanian Council of Research "FOREstRESS" (SIT- 3/2015).
\end{abstract}

Keywords: Scots pine, defoliation, stem basal area, meteorology, acidifying compounds, ozone

\section{INTRODUCTION}

Increases in carbon dioxide $\left(\mathrm{CO}_{2}\right)$ concentrations, air temperature and changes in chemical atmospheric composition (sulphur $(\mathrm{S})$ and nitrogen $(\mathrm{N})$ deposition and surface ozone $\left(\mathrm{O}_{3}\right)$ concentrations), might change tree competition status, as well as nutrient and light availability, what in general can result the sustainability of forest (De Vries et al., 2009; Laubhann et al., 2009; Solberg et al., 2009; Dobbertin et al., 2013; Sicard et al., 2016). Crown condition and stem increment rate of the trees in stands are one of the main response variables revealing stand sustainability the best. Tree growth, which is expressed by annual tree-ring formation, is one of the best indicators of tree vitality and the general state of forests during long term periods (Kairiukstis et al., 1987; Cook, 1987; Dobbertin, 2005; Dobbertin et al., 2013). The anatomic structure of trees creates unique possibilities for the retrospective assessment of growth rate for a long period based on annual tree-ring analysis (Juknys et al., 2014). Therefore, in the present study, the characteristics of tree-ring width formation of Scots pine (Pinus sylvestris L.) which is a prevailing in Lithuania tree species for the last 30-year period were investigated. The existing data revealed that the width of annual tree rings is highly sensitive to climate change and air pollutants (Schweingruber, 1996; McLaughlin et al., 2002; De Vries et al., 2014). In Lithuania pine growth was mainly related to air temperatures of late winter (February), early spring (March, April) and late summer (August) of the current year and the temperatures of autumn of the last year (September and October).The effect of precipitation is less essential than the effect of temperature (Augustaitis et al., 2015; Juknys, 2003, 2014).In Europe, long range transboundary pollution and ensuing acidification of the environment

Copyright (C) 2017 The Authors. Published by Aleksandras Stulginskis University. This is an open-access article distributed under the terms of the Creative Commons Attribution License (CC-BY 4.0), which permits unrestricted use, distribution, and reproduction in any medium, provided the original author and source are credited. 
were implicated as major causes of these forest declines on a regional scale (Bauer, 1982; Knabe, 1981; Mehne-Jakobs, 1990). A few years later scientific advances suggested that only in exceptional cases does environmental pollution appear as a single factor. In most cases a multitude of stress factors including unfavourable climatic conditions, attacks of forest pests and diseases contribute to the deterioration of forest conditions (Auclair et al., 1992; De Vries et al., 2000; Houston, 1992; Neirynck \& Roskams, 1999; Ratio, 2000). The findings in Lithuania allowed us to make an assumption, that temporal changes in pine defoliation are first of all related to air concentrations of acidifying compounds and their deposition, while unfavourable climatic conditions could only reinforce the integrated impact of these factors (Augustaitis et al. 2005, 2007). However, recently, rapid changes in climate condition became one of the key factors comprising the global change threat to forest condition (Percy and Ferretti 2004, Langner et al. 2005, Zlatev and Moseholm 2008, Jacob and Winner 2009) which could be reinforced by herbivore forest pests (Augustaitis, 2007). Drought over the vegetation period and hard winters could reduce resistance of trees to other unfavourable environmental factors, including air pollution or damage tree physiological processes directly. Vice versa, pollutants can modify responses of ecosystems to specific climatic change impacts (Bytnerowicz et al. 2007). Therefore, it is still unclear whether local meteorological conditions reduce or enhance air pollution effects on forest health. Therefore, to identify knowledge gaps and research needs, it is necessary to include interactions between changes in air quality, climate and other site factors on forest ecosystem responses (Matyssek et al., 2012), i.e., as in the present study on tree-ring width formation and changes in crown defoliation. In this concern, the aim of this study was to evaluate the sensitivity of Scots pine trees to recent environmental changes in Lithuania. To achieve the goals of this study, we attempted to determine:

- the main tendencies in pine tree crown defoliation and key contributing factors

- the main tendencies in pine tree ring formation and key contributing factors

- the resilience and adaptive capacity of Scots pine trees to recent environmental changes.

\section{OBJECT AND METHODS}

\section{Site description}

The study was based on monitoring data on crown defoliation of more than 3000 Scots pine (Pinus sylvestris L.) trees from 20 permanent observation stands (POS) annually obtained between 1992 and 2015 in Aukstaitija national park (ANP), located in the eastern part of Lithuania (Fig. 1). All stands represent the prevailing in Lithuania Pinetum vacciniomyrtilosum forest type.
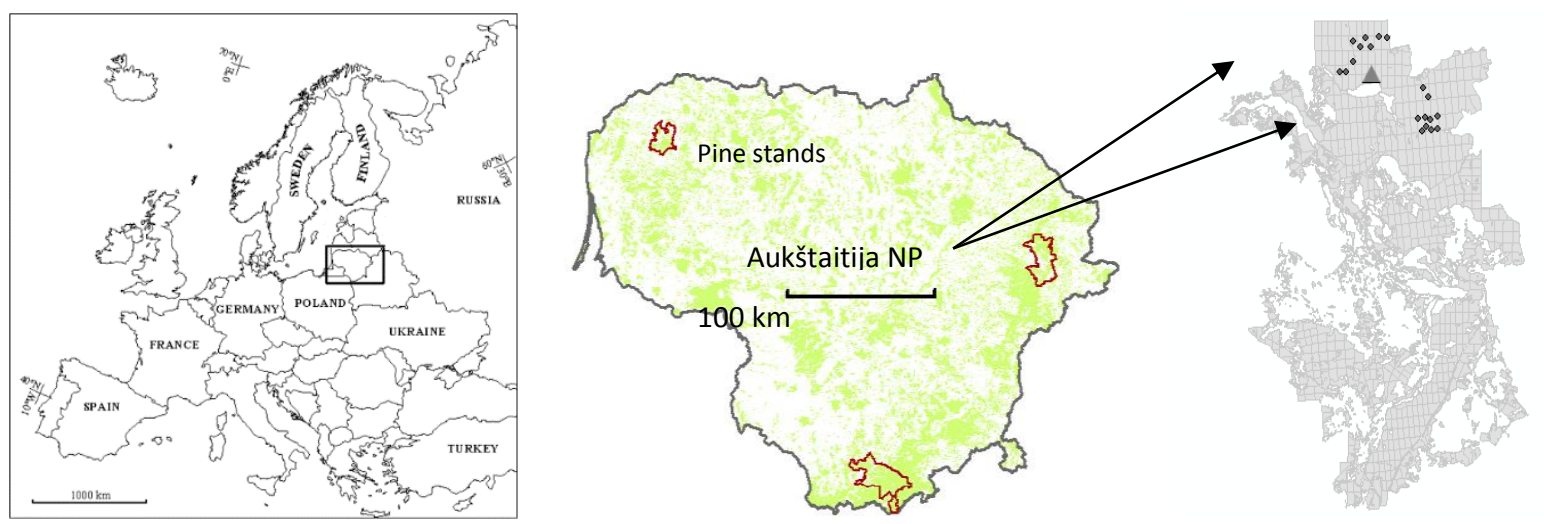

Figure 1. Location of permanent observation pine stands in Aukstaitija NP.

Detailed investigation of tree-ring formation of the considered tree species was performed on two typical mixedmature forest sites at the Aukstaitija Integrated Monitoring Station (IMS). The soil type FS-1 was a Haplic Arenosol, with a water table deeper than $2 \mathrm{~m}$. The dry bulk density in the upper soil layer (AB) was $1.43 \mathrm{~g} \mathrm{~cm}^{-3}$, whereas in the deeper soil layer (B1), it was $1.52 \mathrm{~g} \mathrm{~cm}^{-3}$. The soil type FS-2 was a Terric Histosol, with a water table depth of approximately $0.5 \mathrm{~m}$. The dry bulk density in the upper soil layer (H1) was $0.186 \mathrm{~g} \mathrm{~cm}^{-3}$, and in the deeper soil layer (H2), it was $0.168 \mathrm{~g} \mathrm{~cm}^{-3}$.

Different time periods were used to meet the objectives of the study. To detect effect of meteorology on tree ring width formation data set of meteorology since 1980 was used, while to detect their effect on pine crown defoliation - data set since 1994 was used. The long-term mean annual temperature at the Aukstaitija IMS fluctuated between $+4.0^{\circ} \mathrm{C}(1987)$ and $+8.2^{\circ} \mathrm{C}(2007)$, with an increasing trend of approximately $0.043^{\circ} \mathrm{C}$ per year. Since 1994 this increase in temperature was a little lover and made $0.035^{\circ} \mathrm{C}$ per year.

An analysis of annual precipitation since 1980 revealed a tendency towards increases in precipitation amounts of approximately $0.35 \mathrm{~mm}$ per year, while since 1994 - decreases by $0.19 \mathrm{~mm}$ per year was found. These changes were not significant, however could have had a significant effect on changes in mean crown defoliation and stem increment formation.

Data on air concentrations of sulphur dioxide $\left(\mathrm{SO}_{2}\right)$, sulphate $\left(\mathrm{SO}_{4}{ }^{2-}\right)$, the sum of nitrate species $\left(\Sigma \mathrm{NO}_{3}{ }^{-}=\mathrm{NO}_{3}{ }^{-}\right.$ $\left.+\mathrm{HNO}_{3}\right)$, the sum of ammonium species $\left(\Sigma \mathrm{NH}_{4}{ }^{+}=\mathrm{NH}_{4}{ }^{+}+\mathrm{NH}_{3}\right)$ and the deposition of $\mathrm{SO}_{4}{ }^{2-}$ and $\left.\mathrm{NO}_{3}{ }^{-}, \mathrm{NH}_{4}{ }^{+}\right)$based on a quality-assurance/quality-control (QA/QC) programme (EMEP, 1977) have been collected since 1994 from the Aukstaitija IMS, which is located near the considered forest sites and were presented in detail in earlier manuscripts (Sopauskiene et al., 2001; Augustaitis, 2011; Augustaitis et al., 2007, 2015, 2018). 


\section{Data analysis and statistical methods}

The effects of environmental factors on tree-ring width datasets were studied by response function analysis (Cook and Kairiukstis, 1990; Kairiukstis et al., 1987; Juknys et al., 2014). The widths of the annual tree rings in the stem cores were measured to the closest $0.01 \mathrm{~mm}$ using an electronic transducer and a binocular scope fixed over the moving stage of "Lintab6" equipment. The individual tree-ring width series were synchronized by visual comparison of the ring width graphs (Eckstein, 1989) and statistically by calculating Pearson's coefficients of correlation among them (Baillie \& Pilcher 1973). To eliminate the effect of age on tree-ring width (Holmes 1994), the stem basal area increment (BAI) was computed.

The meteorological parameters for the two last and a current season from September through August were used to identify the key factors driving to the variation in tree-growth intensity and changes in crown defoliation on selected FSs at the Aukstaitija IMS. A Pearson's correlation analysis was used to meet the aim of the sudy. The significance of each predictor variable was detected by applying a level of significance of $\mathrm{p}<0.05$.

Multiple regression models were employed to assess the integrated effect of the considered environmental parameters (meteorology, acid contaminants and surface ozone) on the considered response variables of prevailing in Lithuanian tree species - Scots pine using the linear multiple regression technique of "Statistica 7.0". When creating multiple regression models, the selected predict parameters were excluded from the regression model using a stepwise procedure based on their lowest level of significance (Eckstein 1989; Draper \& Smith 1998). A determination coefficient $R^{2}$ with $p<0.05$ was used to assess the performance of the model.

\section{RESULTS}

Air temperature and moisture are environmental factors that clearly influence forest condition and growth, and both are predicted to change with changing climate (Fernandez, 1997). The obtained data revealed that during the last 24 years mean defoliation of Scots pine trees had a trend towards decreasing by $0.25 \%$ per year and this trend was significant $(\mathrm{p}<0.05)$ (Fig. 2). The years when the condition of Scots pine trees was the worst were as follows: 1995, 2003 and 2010 , while the best -2005 and 2015.
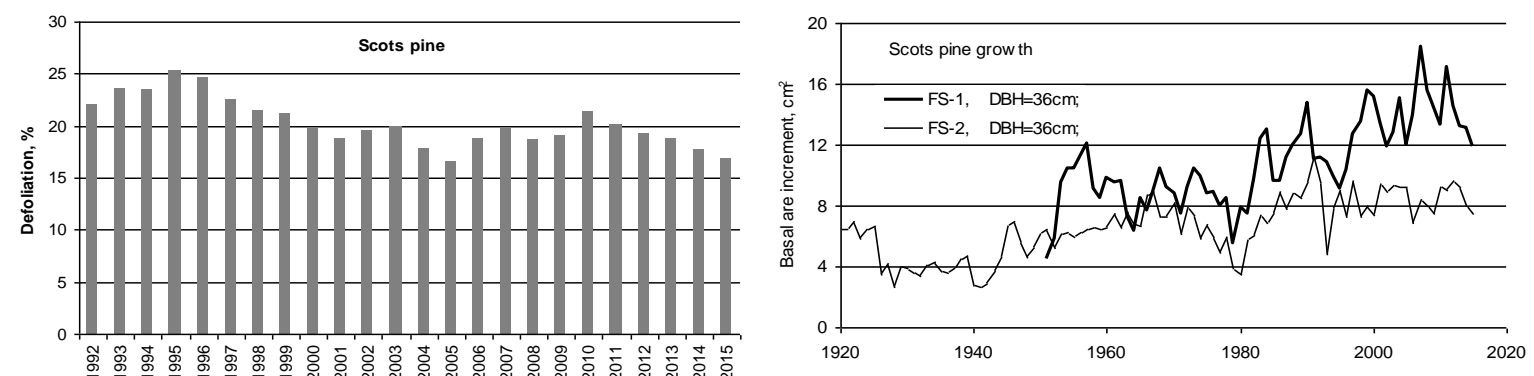

Figure 2. Variation in Scots pine crown defoliation and stem BAI formation at different forest sites in Aukštaitija NP.

The data obtained for Europe, including Lithuania, revealed an increasing tree-growth rate (Speaker 1995; Augustaitis et al., 2015). The obtained data revealed that the increases in tree-ring width were typical for pine trees aged 70 to $90(\mathrm{p}<0.05)$ which ensured on mineral FS-1 rapid increase in BAI by about $0.1 \mathrm{~cm}^{2}$ per year (Fig. 2). Mature and over-mature trees, the age of which exceeded 100 years, demonstrated a stable incremental growth rate for nearly the last 30 - 40 years. This growth intensity indicated a gradual increase in stem BAI on organic 2 FS- $20.05 \mathrm{~cm}^{2}$ per year.

\section{Effect of environmental factors on Scots pine crown defoliation}

Key factors which resulted in the detected pine defoliation trend were air concentration of acidifying compounds and their deposition (Fig. 3). Effect of meteorology was remarkably lover. However, analyses, based on data from the ICP Forest Monitoring level I network, yielded ambiguous results (Ozolincius \& Stakenas, 2001; Ozolincius et al., 2005). The researchers noted that temperature had a negative effect on tree conditions, explaining up to $72 \%$ of the temporal variation in mean annual defoliation of Scots pine in Lithuania. Our data revealed that higher air temperature resulted in improvement of Scots pine crown condition. Only heat in June resulted in its deterioration.
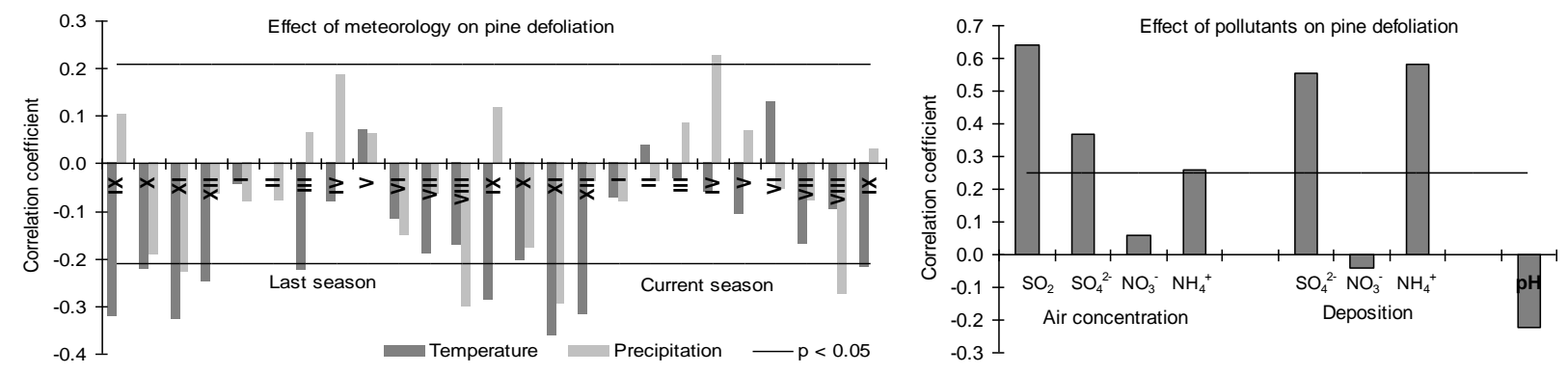

Figure 3. Effect of meteorology and air pollutants on the variation in mean crown defoliation of Scots pine trees. 
Table 1. Multigeression model of Scots pine tree defoliation in relation to meteorology and air pollutants.

\begin{tabular}{|l|r|r|r|r|r|r|}
\hline \multirow{2}{*}{ Predict variables } & \multicolumn{7}{|c|}{$\begin{array}{c}\text { Regression Summary for Dependent Variable Pine defoliation: } \\
\mathrm{R}=0.732 \mathrm{R}^{2}=0.535 \mathrm{~F}(5,18)=13.6 \mathrm{p}<0.000 \text { Std.Er. of est.: 3.78 }\end{array}$} \\
\cline { 2 - 7 } & \multicolumn{1}{|c|}{ Beta } & Std.Err. of Beta & \multicolumn{1}{c|}{$\mathrm{B}$} & \multicolumn{1}{c|}{ Std.Err. } & $\mathrm{t}(59)$ & $\mathrm{p}$-level \\
\hline Intercept & & & 2.239 & 5.582 & 0.401 & 0.690 \\
\hline Air SO $\mathrm{SO}_{2}$ & 0.437 & 0.116 & 3.419 & 0.910 & 3.756 & 0.000 \\
\hline Dep NH${ }_{4}^{+}$ & 0.294 & 0.115 & 0.014 & 0.005 & 2.565 & 0.013 \\
\hline Tm XII & -0.160 & 0.095 & -0.256 & 0.152 & -1.688 & 0.097 \\
\hline Tm VI & 0.233 & 0.092 & 0.847 & 0.334 & 2.537 & 0.014 \\
\hline Pr VIII & -0.131 & 0.099 & -0.014 & 0.010 & -1.320 & 0.192 \\
\hline
\end{tabular}

Integrated effect of meteorology and pollutants explained more than $53 \%$ variation in pine defoliation of Scots pine trees at Aukštaitija NP (Table 1). Effect of acidifying compounds and their deposition was more significant explaining changes in the considered response variables than meteorology. Of the key air pollutants which had the most significant effect on pine crown defoliation was $\mathrm{SO}_{2}$. The effect of ammonium deposition the amount of which over the last period had tendency to increase also demonstrated high significance. These results allowed concluding that pollutants remained one of the most important environmental factors, notwithstanding the fact that due to emission control in central and western parts of Europe regional pollution load decreased more than tenfold. Higher air concentration of acidifying compounds and deposition load together with heat during June should result in pine crown condition deterioration, while wormer December and more abundant precipitation in August should mitigate this negative effect. Based on the recent tendencies in detected key parameters we concluded that pine condition stabilized or further will improve. The obtained results well agreed with results presented up to 10 years ago (Augustaitis et al., 2005, 2010a, 2010b) what proved that earlier detected regularities remained are still significant under the present presses of changes in environmental condition.

\section{Effect of environmental factors on Scots pine tree stem BAI formation}

The obtained data on effect of meteorology was in full agreement with the state of knowledge in this area. The effect of temperature was more significant on growth regularities of Scots pine trees than that of precipitation (Fig. 4). Cold dormant period, from December through April limited pine growth especially on mineral soil FS-1. The effect of temperature over vegetation period was not as significant as that of dormant period and only warmer July-August resulted in better tree growth condition especially on organic peat land FS-2.

Significance of the effect of precipitation on pine growth was remarkably lover (Fig. 4). Only precipitation during June resulted in more intensive BAI formation on both forest sites. But this effect was only close to the level of significance $(\mathrm{p}<0.01)$. More abundant precipitation amount over January through February had a positive effect on BAI formation in the coming year especially on mineral soil FS-1. Reduction in precipitation amount over September and April negatively affected tree stem BAI formation also only on mineral soil FS where trees could suffer from the lack of humidity.
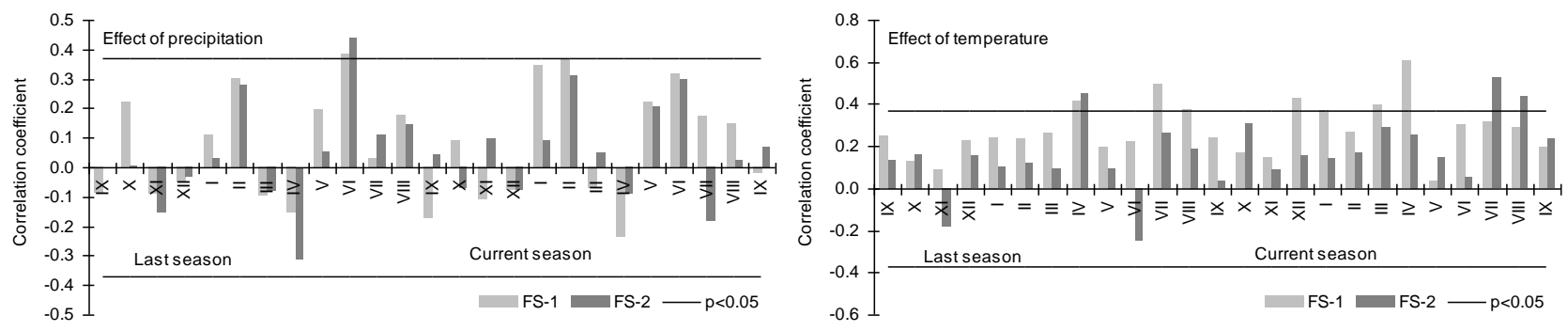

Figure 4. Effect of monthly precipitation amount and mean air temperature of two seasons on Scots pine BAI formation.

Developed Scots pine tree growth models revealed that on organic FS-2, more precipitation during February, June and July of the last year and February of the current season, together with a higher temperature in October and March of the current season, resulted in a higher BAI rate in pine trees, explaining up to $66 \%$ variation in BAI formation. Only the heat in June of the last season negatively affected the tree growth rate by reducing it (Equation 1):

$\mathbf{Z q}$ (pine) $\mathbf{F S}-2=8.46+0.0282 \times \operatorname{Pr}_{(\mathrm{II})}{ }^{-1}+0.0123 \times \operatorname{Pr}_{(\mathrm{VII})}{ }^{-1}+0.017 \times \operatorname{Pr}_{(\mathrm{VII})}{ }^{-1}+0.0192 \times \operatorname{Pr}_{(\mathrm{II})}-0.301 \times \operatorname{Tm}_{(\mathrm{VI})}{ }^{-1}+0.224 \times \operatorname{Tm}_{(\mathrm{X})}+$
$+0.150 \times \mathrm{Tm}_{(\mathrm{III})} ;$
$R^{2}=0.661$, Std.Err.: $1.0 ;$ Statistic: $F(7,28)=7.7, p<0.000 ;$

On mineral FS-1 soil, only higher temperatures in September, July of the last season and November, April and June of the current season stimulated a more intensive pine growth rate (Equation 2), explaining up to 64\% variation in BAI formation. Neither the negative effect of heat in June nor a significant effect of precipitation was detected there:

$\mathbf{Z q}$ (pine) FS-1 =-35.68+1.212× $\operatorname{Tm}_{(\mathrm{IX})}{ }^{-1}+0.940 \times \mathrm{Tm}_{(\mathrm{VII})}{ }^{-1}+0.877 \times \mathrm{Tm}_{(\mathrm{XI})}+1.034 \times \mathrm{Tm}_{(\mathrm{IV})}+0.904 \times \mathrm{Tm}_{(\mathrm{VI})} ;$
$R^{2}=0.641$, Std.Err.: 3.3; Statistic: $F(5.30)=10.7, p<0.000 ;$

There parameters with index "-1" indicates last season, without index - current season 
Air concentration of acidifying compounds and their deposition had a negative effect on BAI formation and first of all on mineral soil FS-1 (Fig. 5). The effect of these pollutants on pine BAI formation was more significantly expressed over the current season than over the last. Higher air concentration of acidifying compounds mainly resulted in inhabitation of stem BAI formation over the both dormant and vegetation periods, while deposition load mainly by $\mathrm{N}$ compounds having a negative effect over the dormant period, resulted in more intensive BAI formation over vegetation. It confirmed the state of knowledge, that $\mathrm{N}$ compounds, when their concentrations did not exceed the critical values positively affected tree ring formation (Holmberg et al., 2013; Agustaitis and Bytnerowicz, 2008, Augustaitis et al., 2007, 2015).

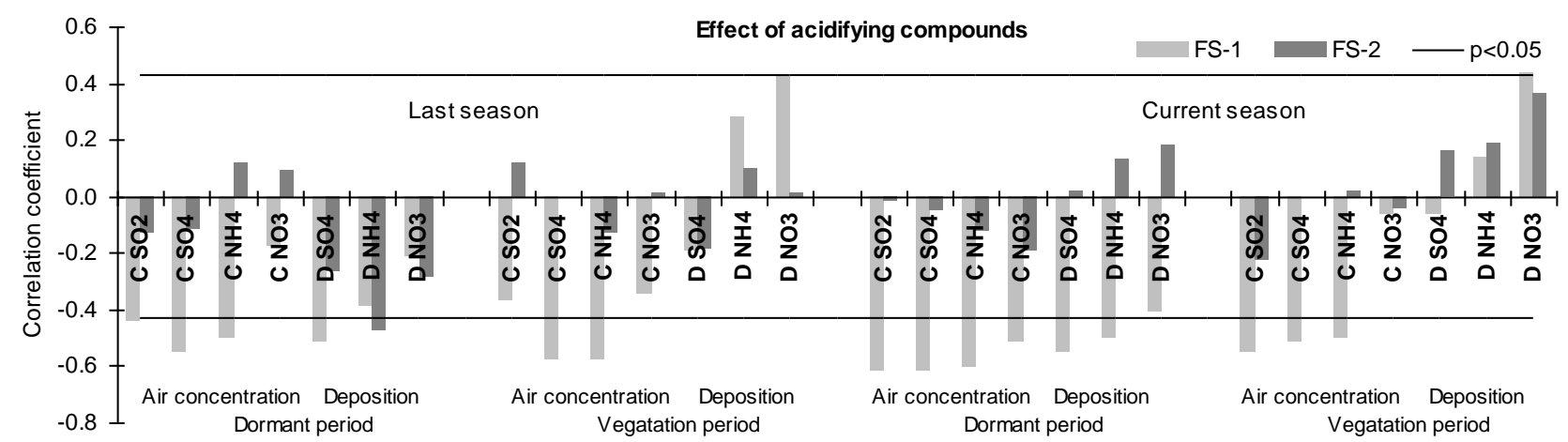

Figure 6. Effect of acidifying compounds over the dormant and vegetation periods of last and current seasons on pine BAI formation on different FS. Air concentration of acidifying compounds with index " $C$ ", deposition with index " $D$ "

Nitrate deposition during the entire current season stimulated increasingly changing pine tree-ring formation on organic FS-2 soil (Equation 3). Reduced air concentrations of $\mathrm{SO}_{2}$ and slightly increased $\mathrm{NO}_{3}{ }^{-}$deposition during the vegetative period were responsible for the increased incremental growth rate of pine BAI on mineral soil FS-1 (Equation 4):

$$
\begin{aligned}
& \mathbf{Z q} \text { (pine) } \mathbf{F S - 2}=5.74+0.0101 \times \operatorname{DrDep}\left(\mathrm{NO}_{3}{ }^{-}\right)+0.0236 \times \mathrm{VgDep}\left(\mathrm{NO}_{3}{ }^{-}\right) \text {; } \\
& R^{2}=0.214 \text {, Std.Err.: 0.85; Statistic: } F(2.18)=2.44 p<0.114 \text {; } \\
& R^{2}=0.566 \text {, Std.Err.: 2.5; Statistic: } F(3.17)=7.39 p<0.002 \text {; }
\end{aligned}
$$

The scientists investigating increases in tree growth indicated a fertilising effect from nitrogen deposition. It is well known that nitrogen deposition affects forest ecosystems through $\mathrm{N}$ enrichment and the acidification of soils, tree growth and conditions, finally resulting in increases to susceptibility to secondary stress, such as drought, frost, pathogens or pests (Paoletti et al., 2007; de Vries et al., 2009; Bobbink et al., 2010; Dobbertin, et al., 2013). However, the effect of these pollutants first of all depends on the deposition level and initial $\mathrm{N}$ enrichment of forest sites.

A reduction in sulphur emissions after the implementation of international legislation was usually considered to be a predisposing driver of the recovery process in forests (Spiecker, 1995; Solberg et al., 2009; de Vries, Posh, 2011). Recently, a more than tenfold reduced $\mathrm{S}$ deposition and air concentrations of $\mathrm{SO}_{2}$ on a regional scale initiated recovery in tree growth intensity, especially on mineral FS-1, which is reflected in the models developed in the study.

The integrated effect of the meteorology, air concentration of acidifying compounds and their deposition on BAI variation revealed that meteorological parameters adversely to crown defoliation were mainly responsible for the detected changes in BAI formation from 1995-2015. During this period they explained up to 64- 69\% of the variation in the BAI of pine trees on considered FS's. The air concentration of acidifying compounds, their deposition and surface ozone were the factors that the effect of which on changes in BAI was least significant especially on organic soil FS-2 (Table 2). The resented models allowed for detecting that higher moisture regime and nutrition sources on FS-2 mitigate the negative effect of acidifying compounds on tree BAI formation. Reduction in air $\mathrm{SO}_{2}$ concentrations mainly over the dormant and

\begin{tabular}{|c|c|c|c|c|c|c|c|c|}
\hline \multirow{2}{*}{$\begin{array}{l}\text { Model: } \\
\text { Variables }\end{array}$} & \multicolumn{4}{|c|}{$\begin{array}{l}\text { Regression Summary for Variable Pine FS-1: } \\
R=0.861 R^{2}=0.741 F(3,17)=12.89 p<0.05\end{array}$} & \multicolumn{4}{|c|}{$\begin{array}{l}\text { Regression Summary for Variable: Pine FS-2: } \\
R=0.760 \mathrm{R}^{2}=0.577 \mathrm{~F}(3,17)=6.85 \mathrm{p}<0.05\end{array}$} \\
\hline & B & $\begin{array}{l}\text { Std.Err. } \\
\text { of B }\end{array}$ & $\mathrm{t}(18)$ & p-level & B & $\begin{array}{l}\text { Std.Err. } \\
\text { of B }\end{array}$ & $\mathrm{t}(18)$ & p-level \\
\hline Intercept & 5.056 & 9.293 & 0.544 & 0.593 & 1.074 & 3.744 & 0.286 & 0.777 \\
\hline Meteorology & 0.556 & 0.163 & 3.409 & 0.003 & 0.451 & 0.165 & 2.722 & 0.014 \\
\hline Acid. compound & 0.415 & 0.282 & 1.467 & 0.065 & 0.534 & 0.334 & 1.595 & 0.129 \\
\hline Surface ozone & -0.080 & 0.104 & -0.769 & 0.152 & -0.015 & 0.032 & -0.484 & 0.633 \\
\hline
\end{tabular}
slight increase in nitrate deposition over the vegetative period became key factors that were responsible not only for recovery of crown condition but also for more intensive stems BAI formation of Scots pine trees.

Table 2. Multiregression models of pine growth on different FS in relation to meteorology and acidifying compounds.

Note: Statistically significant group or variable in bold.

\section{Resilience and adaptive capacity of Scots pine trees to recent environmental changes}

Generalising the obtained results we could state that Scot pine trees are likely to be the most sensitive and most resilient tree species to environmental changes in hemi-boreal forests. These results contradict the findings obtained in 
central or southern Europe, where the incremental growth of Scots pine trees was found to be least sensitive to environmental changes (Seidling et al., 2012). The results obtained in our earlier studies indicate that meteorology and acidifying compounds most significantly explained the variation in crown defoliation of Scots pine trees (Augustaitis et al., 2010a, 2010b, Augustaitis, 2011) and what quite well reflected in spectral reflectance properties of pine tree needles (Masaitis et al., 2013). In the present study, these findings were confirmed in the area of stem BAI formation on both considered forest sites. Climate conditions had a strong influence on the growth intensity of trees (Scharnweber et al., 2011), and to a lower extent these variables resulted in changes in mean defoliation. The created models indicated that a warm vegetative period was one of the main drivers of intensive pine growth. It also reinforced the positive effect of reduced pollution load on pine tree crown defoliation.

Different humidity regime revealed that pine trees growing on drier mineral FS-1 soil, with a natural moisture regime, had no higher requirement for higher precipitation, which indicated their very high resistance to the drought effect. For typical Scots pine trees on mineral FS-1 soil, only positive effects from temperature during the dormant and vegetative period were detected. These findings reflect well the statements presented by de Vries and Posch (2011), who stated that the change in forest growth and carbon sequestration in the past was dominated by changes in nitrogen deposition, whereas climate change is the major driver of future carbon sequestration, the impact of which, in the future, can be reduced by nitrogen availability.

\section{CONCLUSIONS}

Crown defoliation of Scots pine trees is closely related to air concentrations and wet deposition of the acidifying compounds. The obtained results indicated that higher amount of precipitation over the vegetation and warmer dormant periods were shown to be the key factors positively affecting pine crown condition, reducing their mean defoliation. In future only cold dormant period and heat in June can alter sustainability of Scots pines, reducing their tolerance to phytotoxic effects of air pollutants, including surface ozone and acid deposition in north-eastern part of Lithuania.

Significant increases in air temperature in September and July increased the BAI of the considered coniferous tree species. Only heat and drought in June limited spruce growth intensity on both FSs and pine trees on organic FS-2 soil under an excessive moisture regime.

A higher moisture regime significantly increased the tolerance of the considered tree species to the negative effects of air concentrations.

\section{ACKNOWLEDGEMENT}

The study is based on the results obtained conducting national project supported by Lithuanian Council of Research "FOREstRESS" (SIT- 3/2015).

\section{REFERENCES}

1. Auclair A. N. D., Worrest R. C., Lachance D., Martin H. C. 1992. Climatic perturbation as a general mechanism of forest dieback. In P. D. Manion \& D. Lachance (Eds.), Forest decline concepts, pp. 38-58. Minnesota: St. Paul.

2. Augustaitis, Algirdas. 2007. Pine sawfly (Diprion pini L.) - Related changes in Scots pine crown defoliation and possibilities of recovery. Polish Journal of Environmental Studies, Vol. 16, pp. 363-369.

3. Augustaitis, A., 2011. Impact of Meteorological Parameters on Responses of Pine Crown Condition to Acid Deposition at Aukštaitija National Park. Baltic Forestry, No. 17, pp. 205-214.

4. Augustaitis, A., Augustaitiene, I., Kliucius, A., Bartkevicius, E., Mozgeris, G., Sopauskiene, D., Eitminaviciute, I., Arbaciauskas, K., Mazeikyte, R., Bauziene I. 2005. Impact of acidity components in the air and their deposition on biota in forest ecosystems. Baltic Forestry, No. 2, pp. 84-93.

5. Augustaitis, A., Augustaitienė, I., Činga, G., Mažeika, J., Deltuvas, R., Juknys, R., Vitas, A. 2007. Did the Ambient Ozone Affect Stem Increment of Scots Pines (Pinus sylvestris L.) on Territories under Regional Pollution Load? Step III of Lithuanian Studies. The Scientific World Journal, Vol. 7, pp. 58-66. https://doi.org/10.1100/tsw.2007.55

6. Augustaitis, A., Augustaitienè, I., Kliučius, A., Pivoras, G., Šopauskienè, D., Girgždienė, R. 2010a. The seasonal variability of air pollution effects on pine conditions under changing climates. European Journal of Forest Research, Vol. 129, pp. 431-441. https://doi.org/10.1007/s10342-009-0319-x

7. Augustaitis, A., Šopauskienè, D., Baužienė, I., 2010b. Direct and Indirect Effects of Regional Air Pollution on Tree Crown Defoliation. Baltic Forestry, No. 16, pp. 23-34.

8. Augustaitis, A., Augustaitienė, I., Mozgeris, G., Juknys, R., Vitas, A., Jasinevičienè, D. 2015. Growth patterns of Scots pine (Pinus sylvestris L.) under the current regional pollution load in Lithuania. iForest, No. 8, pp. 509-516.

9. Augustaitis, A., Augustaitienė, I., Baugarten, M., Bičenkienė, S., Girgždienè, R., Kulbokas, G., Linkevičius, E., Marozas, V., Mikalajūnas, M., Mordas, G., Mozgeris, G., Petrauskas, E., Pivoras, A., Šidlauskas, G., Ulevičius, V., Vitas, A., Matyssek, R. 2018. Tree-ring formation as an indicator of forest capacity to adapt to the main threats of environmental changes in Lithuania. Science of the Total Environment, Vol. 615, pp. 1247-1261. https://doi.org/10.1016/j.scitotenv.2017.09.169

10. Augustaitis, A., Bytnerowicz, A. 2008. Contribution of ambient ozone to Scots pine defoliation and reduced growth in the Central European forests: A Lithuanian case study. Environmental Pollution, Vol. 155, pp. $436-445$. https://doi.org/10.1016/j.envpol.2008.01.042

11. Baillie, M.G.L., Pilcher, J.R., 1973. A simple cross-dating program for tree-ring research. Tree-Ring Bulletin, Vol. 33, pp. 7-14.

12. Bauer, F. 1982. Kommt es forstlich zur Katastrophe? Allgemeine Forstzeitschrift, Vol. 29, pp. 865-867. 
13. Bobbink, R., Hicks, K., Galloway, J., Spranger, T., Alkemade, R., Ashmore, M., Bustamante, M., Cinderby, S., Davidson, E., Dentener, F., Emmett, B., Erisman, J.W., Fenn, M., Gilliam, F., Nordin, A., Pardo, L., de Vries, W. 2010. Global assessment of nitrogen deposition effects on terrestrial plant diversity: a synthesis. Ecological Applications, Vol. 20, pp. 30-59. https://doi.org/10.1890/08-1140.1

14. Bytnerowicz A., Omasa, K., Paoletti E. 2007. Integrated effects of air pollution and climate change on forests: A northern hemisphere perspective. Environmental Pollution, Vol. 147, pp. 438-445. https://doi.org/10.1016/j.envpol.2006.08.028

15. Cook, E.R. 1987. The decomposition of tree ring series for environmental studies. Tree-Ring Bulletin, Vol. 47, pp. 37-59.

16. Cook, E.R., Kairiukstis L.A. 1990. Methods of Dendrochronology - Applications in the Environmental Sciences. Dordrecht, Kluwer Academic Publishers and International Institute for Applied Systems Analysis, The Netherlands. https://doi.org/10.1007/978-94-015-7879-0

17. De Vries W., Klap J., Erisman J. W. 2000. Effects of environmental stress on forest crown condition in Europe. Part I: Hypotheses and approach to the study. Water, Air, and Soil Pollution, Vol. 119, pp. 317-333. https://doi.org/10.1023/A:1005157509454

18. De Vries, W., Dobbertin, M.H., Solberg, S., van Dobben, H.F., Schaub, M., 2014. Impacts of acid deposition, ozone exposure and weather conditions on forest ecosystems in Europe: an overview. Plant Soil, Vol. 380, pp. 1-45. https://doi.org/10.1007/s11104-014-2056-2

19. De Vries, W., Posh, M. 2011. Modelling the impact of nitrogen deposition, climate change and nutrient limitation on tree carbon sequestration in Europe for the period 1900-2050. Environmental Pollution, Vol. 159, pp. 2289-2299. https://doi.org/10.1016/j.envpol.2010.11.023

20. De Vries, W., Solberg, S., Dobbertin, M., Sterbad, H., Laubhannd, D., van Oijene, M., Evansf, C., Gunderseng, P., Krosa, J., Wamelinka, G.W.W., Reindsa, G.J., Sutton, M.A. 2009. The impact of nitrogen deposition on carbon sequestration in European forests and heathlands. Forest Ecology and Management, Vol. 258, pp. 1814-1823. https://doi.org/10.1016/j.foreco.2009.02.034

21. Dobbertin, M. 2005. Tree growth as indicator of tree vitality and of tree reaction to environmental stress: a review. European Journal of Forest Research, Vol. 124, pp. 319-333. https://doi.org/10.1007/s10342-005-0085-3

22. Dobbertin, M., Neumann, M., Schroeck, H.W., 2013. Tree Growth Measurements in Long-Term Forest Monitoring in Europe, In: Ferretti, M., Fischer, R. (Eds.), Forest Monitoring - Methods for terrestrial investigations in Europe with an overview of North America and Asia. Developments in Environmental Science, Vol. 12, pp. 183-204.https://doi.org/10.1016/B978-0-08-0982229.00010-8

23. Draper, N.R., Smith, H. 1998. Applied regression analysis (3rd edn). Wiley, New York, USA. https://doi.org/10.1002/9781118625590

24. Eckstein, D., Krause, C., Bauch, J. 1989. Dendroecological investigation of spruce trees (Picea abies (L.) Karst.) of different damage and canopy classes. Holzforschung, Vol. 43, pp. 411-417. https://doi.org/10.1515/hfsg.1989.43.6.411

25. Fernandez I.J. 1997. Climate change and forest ecosystems. Workshop Summary reports of New England regional climate change impacts Workshop. September 3-5. Institute for the Study of Earth, Oceans, and Space, University of New Hampshire, Durham, NH. Available at: http://www.necci.sr.unh.edu/necci-report/fernand.pdf

26. Holmes, E. E., Lewis, M. A., Banks, J. E. and Veit, R. R. 1994. Partial Differential Equations in Ecology: Spatial Interactions and Population Dynamics. Ecology, Vol. 75, pp. 17-29. https://doi.org/10.2307/1939378

27. Holmberg, M.; Vuorenmaaa, J.; Poschb, M.; Forsius, M.; Lundin, L.; Kleemola, S.; Augustaitis, Algirdas; Beudert, B.; Wit, H.A. de; Dirnböck, T.; Evansh, C.D.; Frey, J.; Grandin, U.; Indriksone, I.; Krám, P.; Pompei, E.; Schulte-Bisping, H.; Srybny, A.; Váňa, M. 2013. Relationship between critical load exceedances and empirical impact indicators at Integrated Monitoring sites across Europe. Ecological Indicators, Vol. 24, pp. 256-265. https://doi.org/10.1016/j.ecolind.2012.06.013

28. Houston D. R. 1992. A host-stress-saprogen model for forest dieback-decline diseases. In P. D. Manion \& D. Lachance (Eds.), Forest decline concepts, pp. 3-25. Minnesota: St. Paul.

29. Jacob D.J., Winner D. 2009. Effect of climate change on air quality. Atmospheric Environment 2009, P. 51-63. https://doi.org/10.1016/j.atmosenv.2008.09.051

30. Juknys R., Vensloviene J., Stravinskiene V., Augustaitis A., Bartkevicius E. 2003. Scots pine (Pinus sylvestris L.) growth and condition in a polluted environment: From decline to recovery. Environmental Pollution, Vol. 125, pp. $205-212$. https://doi.org/10.1016/S0269-7491(03)00070-8

31. Juknys, R., Augustaitis, A., Venclovienė, J., Kliučius, A., Adomas, V., Bartkevičius, E., Jurkonis, N. 2014. Dynamic response of tree growth to changing environmental pollution. European Journal of Forest Research, Vol. 133, pp. 713-724. https://doi.org/10.1007/s10342-013-0712-3

32. Kairiukstis, L., Grigaliunas, J., Skuodiene, L., Stravinskiene, V. 1987. Physiological and dendrochronological indications of forest decline and their application for monitoring, in: Kairiukstis, L., Nilsson, S., Straszak, A. (eds), Forest decline and reproduction: regional and global consequences. IIASA, Luxenburg, pp. 151-169.

33. Knabe, W. 1981. Immissionsökologische Waldzustandserfassung in Nordhein-Westfalen. Allgemeine Forstzeitschrift, Vol. 26, pp. 641-643 [In Germany].

34. Langner J., Bergstro R., Foltescu V. 2005. Impact of climate change on surface ozone and deposition of sulphur and nitrogen in Europe. Atmospheric Environment, Vol. 39, pp. 1129-1141. https://doi.org/10.1016/j.atmosenv.2004.09.082

35. Laubhann, D., Sterba, H., Reinds, G.J., De Vries, W. 2009. The impact of atmospheric deposition and climate on forest growth in European monitoring plots: An individual tree growth model. Forest Ecology and Management, Vol. 258, pp. $1751-1761$. https://doi.org/10.1016/j.foreco.2008.09.050

36. Masaitis, G., Mozgeris, G., Augustaitis, A. 2013. Spectral reflectance properties of healthy and stressed coniferous trees. iForest, Vol. 6, pp. 30-36. 
37. Mehne-Jakobs B.M. 1990. Untersuchungen zur Überprufung der Epidemiehypothese als Erklärungsansatz zu den neuartigen Waldschaden. Allgemeine Forst und Jagdzeitung, Vol. 161, pp. 231-239. [In Germany].

38. Matyssek, R., Wieser, G., Calfapietra, C., de Vries, W., Dizengremel, P., Ernst, D., Jolivet, Y., Mikkelsen, T.N., Mohren, G.M.J., Le Thiec, D., Tuovinen, J.-P., Weatherall, A., Paoletti, E. 2012. Forests under climate change and air pollution: gaps in understanding and future directions for research. Environmental Pollution, Vol. 160, pp. 57-65. https://doi.org/10.1016/j.envpol.2011.07.007,

39. McLaughlin, S.B., Shortle, W.C., Smith, K.T. 2002. Dendroecological applications in air pollution and environmental chemistry: research needs. Dendrochronologia, Vol. 20, Iss. 1-2, pp. 133-157. https://doi.org/10.1078/1125-7865-00013

40. Neirynck L., Roskams P. 1999. Relationships between crown condition of beech (Fagus sylvatica L.) and throughfall chemistry. Water, Air, and Soil Pollution, Vol. 116, pp. 389-394. https://doi.org/10.1023/A:1005246807137

41. Ozolincius R., Stakenas V. 2001. Influence of Sulphur Deposition and Drought Stress on Forest Condition in Lithuania. Baltic Forestry, No. 7, pp. 18-23.

42. Ozolincius R., Stakenas, V., Serafinaviciute, B. 2005. Meteorological factors and air pollution in Lithuanian forests: Possible effects on tree condition. Environmental Pollution, Vol. 137, pp. 587-595. https://doi.org/10.1016/j.envpol.2005.01.044

43. Percy K.E., Ferretti, M. 2004. Air pollution and forest health: toward new monitoring concepts. Environmental Pollution, Vol. 130, pp. 113-126. https://doi.org/10.1016/j.envpol.2003.10.034

44. Ratio H. 2000. Weather conditions during 1980-95 and tree damage directly attributable to weather. In E. Mälkönen (Ed.), Forest condition in a changing environment - the Finnish case, pp. 41-48. https://doi.org/10.1007/978-94-015-9373-1_5

45. Paoletti, E., Bytnerowicz, A., Andersen, H.-E., Augustaitis, A., Ferretti, M., Grulke, N., Günthardt-Goergb, M.S., Innes, J., Johnson, D., Karnosky, D., Luangjame, J., Matyssek, R., McNulty, S., Muller - Starck, G., Musselman, R., Percy, K. 2007. Impacts of Air Pollution and Climate Change on Forest Ecosystems - Emerging Research Needs. The Scientific World Journal, , pp. 1-8. https://doi.org/10.1100/tsw.2007.52

46. Scharnweber, T., Manthey, M., Criegee, Ch., Bauwe, A., Schröder, Ch., Wilmking, M. 2011. Drought matters - declining precipitation influences growth of Fagus sylvatica L. and Quercus robur L. in north-eastern Germany. Forest Ecology and Management, Vol. 262, pp. 947-961. https://doi.org/10.1016/j.foreco.2011.05.026

47. Schweingruber, F.H. 1996. Tree rings and environment: dendroecology. Paul Haupt Publishers, Bern.

48. Seidling, W., Ziche, D., Beck, W. 2012. Climate responses and interrelations of stem increment and crown transparency in Norway spruce, Scots pine, and common beech. Forest Ecology and Management, Vol. 284, pp. $196-204$. https://doi.org/10.1016/j.foreco.2012.07.015

49. Sicard, P., Augustaitis, A., Belyazid, S., Calfapietra, C., de Marco, A., Fenn, M., Bytnerowicz, A., Grulke, N., He, S., Matyssek, R., Serengil, Y., Wieser, G., Paoletti, E. 2016. Global topics and novel approaches in the study of air pollution, climate change and forest ecosystems. Environmental Pollution, Vol. 213, pp. 977-987. https://doi.org/10.1016/j.envpol.2016.01.075

50. Solberg, S., Dobbertin, M., Reinds, G.J., Lange, H., Andreassen, K., Fernandez, P.G., Hildingsson, A., de Vries, W. 2009. Analyses of the impact of changes in atmospheric deposition and climate on forest growth in European monitoring plots: a stand growth approach. Forest Ecology and Management, Vol. 258, pp. 1735-1750. https://doi.org/10.1016/j.foreco.2008.09.057

51. Sopauskiene, D., Jasineviciene, D., Stapcinskaite, S. 2001. The effect of changes in European anthropogenic emissions on the concentrations of sulphur and nitrogen components in air and precipitation in Lithuania. Water Air and Soil Pollution, Vol. 130, Iss. 1-4, pp. 517-522. https://doi.org/10.1023/A:1013826411072

52. Spiecker, H., 1995. Growth dynamics in a changing environment - long-term observations. Plant Soil, Vol. 169, pp. 555-561. https://doi.org/10.1007/BF00029368

53. Zlatev Z., Moseholm L. 2008. Impact of climate changes on pollution levels in Denmark. Ecological modeling, Vol. 217, pp.305-319. https://doi.org/10.1016/j.ecolmodel.2008.06.030 